\title{
Comparison of Various Measurement Methods in the Evaluation of Swelling After Third Molar Surgery
}

\section{Üçüncü Molar Diş Cerrahisi Sonrası Şişlik Değerlendirilmesinde Çeşitli Ölçüm Yöntemlerinin Karşılaştııılması}

\author{
Volkan Kaplan $^{1 *}$, Levent Ciğerim ${ }^{2}$, Saadet Çınarsoy Ciğerim ${ }^{3}$, Zeynep Dilan Bazyel ${ }^{2}$, Gönül Dinç $^{3}$ \\ ${ }^{1}$ Tekirdag Namik Kemal University, Faculty of Dentistry, Department of Oral and Maxillofacial Surgery, Tekirdag \\ ${ }^{2} V$ an Yuzuncu Yil University, Faculty of Dentistry, Department of Oral and Maxillofacial Surgery, Van \\ ${ }^{3} V$ an Yuzuncu Yil University, Faculty of Dentistry, Department of Orthodontics, Van
}

\begin{abstract}
Objective: This study aimed to examine the differences between 12 metric swelling evaluation methods in patients undergoing impacted lower third molar surgery.

Material ve Methods: This study was conducted on the patients indicated for the extraction of impacted lower third molar teeth due to orthodontic reasons. Twenty-six patients aged between 18-40 were included in the study. Swelling levels after surgery were measured using anatomic landmarks used for the methods, and the distances between landmarks were measured before the operation, and on days 2 and 7 afterward. The measurements were done using thread and a millimeter ruler while patients were seated. The distances between the anatomical landmarks were evaluated by 12 different methods.

Results: According to the results of the measurements performed on twenty-six patients, (15 male and 11 female) with a mean age of $23.85 \pm 6.06$ years, male had more swelling than female and the difference was statistically significant $(\mathrm{p}<0.05)$ although age, and measurement methods had no significant effect on swelling $(p>0.05)$.

Conclusion: As a result of the present study; twelve swelling evaluation methods showed significantly similar results and the authors recommended using Method 1 and 5 for convenient clinical evaluation which could be performed with a smaller number of anatomical points.
\end{abstract}

Key Words: swelling evaluation, impacted third molar, metric method

\section{Objective}

Nowadays, impacted third molar surgery, with various degrees of complications, is one of the most common surgical procedures in clinical practice. Swelling is the most common

\begin{abstract}
Özet
Amaç: Bu çalışmanın amac1, gömülü alt yirmi yaş diși operasyonu geçiren hastalarda eş zamanlı olarak farklı 12 çevresel şişlik değerlendirme yöntemi kullanılarak, bu yöntemler arasında fark bulunup bulunmadığının tespit edilmesidir.

Gereç ve Yöntem: Bu çalışma, gömülü alt üçüncü molar dişlerin ortodontik nedenlerle çekilme endikasyonu olan hastalarda yapılmıştır. Çalışmaya $18-40$ yaş arasındaki 26 hasta dahil edilmiştir. Operasyondan sonra şişlik seviyeleri anatomik noktalar arasindaki mesafeler, operasyondan önce ve operasyondan sonra 2 . ve 7 günlerde ölçülmüştür. Değerlendirmeler milimetrik cetvel ile hastalar otururken yapılmıştır. Anatomik noktalar arasındaki mesafeler 12 farklı yöntemle değerlendirilmiştir.

Bulgular: Yaş ortalaması 23,85 $\pm 6,06$ y1l olan 26 hastada (15 erkek ve 11 kadın) yapılan ölçüm sonuçlarına göre, daha fazla ödem görülürken $(\mathrm{p}<0,05)$; yaş ve şişlik ölçüm yönteminin şişlik üzerinde anlamlı bir etkisi olmadığı görülmüştür $(\mathrm{p}<0,05)$.

Sonuç: Bu çalışmada, 12 farklı çevresel ödem değerlendirme yönteminin benzer sonuçlar verdiği görülmüştür. Bu sebeple bu yöntemler arasında, daha az sayıda anatomik nokta arasındaki mesafenin ölçülmesini içeren yöntem 1 ve yöntem 5 klinik kullanım için daha kolay değerlendirme tekniği olarak önerilmektedir.
\end{abstract}

Anahtar Kelimeler: şişlik değerlendirme, gömülü üçüncü molar, metrik yöntem

complication after surgery and postoperative swelling reaches its maximum in 1-2 days, begins to decrease in 3 days, and often disappears in 5-7 days (1-6). Post-surgical edema is associated with the inflammatory response due to tissue trauma. After tissue injury, vasodilation occurs, and blood flow to the wound area increases. Increased

\footnotetext{
*Sorumlu Yazar: Volkan Kaplan Tekirdag Namik Kemal University, Faculty of Dentistry, Department of Oral and Maxillofacial Surgery, Tekirdag E-mail: dr.volkankaplan61@gmail.com Tel: 05325041408 Orcid: Volkan Kaplan0000-0002-7605-1125, Levent Ciğerim 0000-0001 5218-8568, Saadet Çınarsoy Ciğerim: 0000-0002-4384-0929, Zeynep Dilan Bazyel 0000-0003-1333-9073, Gönül Dinç 0000-0003-4699-1543 Geliş Tarihi:19.01.2021 , Kabul Tarihi:06.05.2021
} 
vascular permeability leads to the spreading of protein-rich fluid between the tissues, causing swelling (5,7-9). Intraoperative factors such as insufficient irrigation, prolonged operation time, difficulty extracting the impacted tooth, excessive retraction of the flap, and insufficient surgical technique, and individual factors such as age, sex, and the presence of a systemic disease leading to increased postoperative edema (10-13). The literature reports the use of subjective (e.g., Verbal Rating Scale, and Visual Analog Scale) and objective (e.g., Stereophotography, MRI, and metric measurements) methods to measure swelling after impacted third molar tooth surgery $(2,14-16)$. The metric measurement method (circumferential, craniometric, or plethysmographic) is used frequently for being simple, easy, inexpensive, time efficient. It is based on measuring the soft tissue contours between reference points on the face before and after surgery. These reference points are often the angulus mandibula, tragus, ala nasi, corner of the mouth (lip), lateral canthus, the point where the earlobe meets the cheek, and the soft tissue chin tip (pogonion) (2,17-22). According to our literature review, researchers often use only one metric method when evaluating swelling by these reference points. There is no study comparing two or more metric methods in the evaluation of swelling. Therefore, this study aimed to examine the differences between 12 metric swelling evaluation methods simultaneously in patients undergoing impacted third molar surgery.

\section{Material ve Methods}

This study was conducted on the patients that indicated the extraction of impacted lower mandibular third molar teeth due to orthodontic reasons. This study was carried out at the Department of Oral and Maxillofacial Surgery Clinic of Van Yuzuncu Yil University, with approval from the Clinical Research Ethics Committee (No: 2020/04-35). All experiments were conducted in line with the Declaration of Helsinki. Also, written informed consent forms were obtained from all included patients.

Study Sample: The sample for the research consisted of 30 healthy individuals undergoing impacted lower third molar surgery for orthodontic reasons from July to September 2020. Patients, aged 18-40 years, with no pregnancy, no systemic disease (ASA Class I), no drug allergies, with impacted lower third molar with similar angulation position based on Winter's classification (mesioangular or vertical) and similar impaction degree based on Pell and Gregory's classification (Class I, Level C) with bone retention and the necessity to lift bone for extraction, and no medication 1 week before surgery, were included to the study. Patients, with not regularly coming to the controls, using any additional medication that may affect the outcome of the study, the presence of swelling due to infection or allergies to using any drug in the study, and whose operation took more than 30 minutes were excluded from the study.

Surgical Procedure: All procedures were carried out by the surgical team. Two $\mathrm{ml}$ articaine hydrochloride and $40 \mathrm{mg} / \mathrm{ml}$ epinephrine 0.01 $\mathrm{mg} / \mathrm{ml}$ was used as local anesthesia (Maxicaine Fort, VEM Drug, Istanbul, Turkey). A fullthickness three-cornered mucoperiosteal flap was raised, and abundant irrigation was performed for all surgical procedures. After extraction, granulation tissues were removed. Then, the extraction cavities were irrigated using a sterile $0.9 \%$ saline solution. Following bleeding control, mucoperiosteal flaps were repositioned by using 3.0 silk sutures. The patients were prescribed 25 mg dexketoprofen trometamol with a maximum of 2 doses a day postoperatively (Arveles, Ufsa Pharmaceutical Industry, and Trade Co. Ltd. Istanbul, Turkey). All patients were given instructions to follow a soft diet and to avoid mouth washing, brushing, and flossing for the first day. Finally, all patients were prescribed chlorhexidine gluconate 4\% mouthwash (Klorhex $200 \mathrm{ml}$, Drogsan Pharmaceuticals, Ankara, Turkey) with instructions to rinse their mouth 3 times a day for 7 days after surgery.

Data Collection: Swelling levels after surgery were measured using anatomic landmarks, the distances between the landmarks used for the evaluation methods were measured before the operation, and on days 2 and 7 afterward. All measurements were done using thread and a millimeter ruler, while the patients were seated. The distances between the anatomical points were evaluated by 12 different methods that using the averages of single, double, triple, quadruple, or quintet measurements, as reported in the literature or as determined by the researchers (Figure 1, Table 1). Swelling ratios were calculated as (BA) / $A * 100$; where $A$ stands for mean preoperative measurement and $\mathrm{B}$ refers to mean postoperative measurement (postoperative days 2 or 7) (23).

Statistical Analysis The previous researches have reported Standard deviations $(\sigma)$ ranging from 0.56 to 9 for swelling; thus, the standard deviation value was determined as $5(24,25)$. The effect size (d) was calculated as 2 with a $Z$ value of 1.96 and 
Table 1: Descriptions of 12 swelling evaluation methods

\begin{tabular}{|c|c|}
\hline Group & Distance between predetermined facial anatomical landmarks \\
\hline $\begin{array}{l}\text { Method } 1 \text { (Two } \\
\text { measurements) }\end{array}$ & Tragus-Labial comissura, and Tragus-Pogonion (soft tissue) \\
\hline $\begin{array}{l}\text { Method } 2 \text { (Three } \\
\text { measurements) }\end{array}$ & $\begin{array}{c}\text { Tragus-Labial comissura, Tragus-Pogonion (soft tissue), and Mandibular angle- } \\
\text { Lateral corner of the eye }\end{array}$ \\
\hline $\begin{array}{l}\text { Method } 3 \text { (Five } \\
\text { measurements) }\end{array}$ & $\begin{array}{c}\text { Mandibular angle-Tragus, Mandibular angle-Lateral corner of eye, Mandibular } \\
\text { angle-Ala nasi, Mandibular angle-Labial comissura, and Mandibular angle-Pogonion } \\
\text { (soft tissue) }\end{array}$ \\
\hline $\begin{array}{l}\text { Method } 4 \text { (Three } \\
\text { measurements) }\end{array}$ & $\begin{array}{c}\text { Mandibular angle-Lateral corner of eye, Mandibular angle-Labial comissura, and } \\
\text { Tragus-Labial comissura }\end{array}$ \\
\hline $\begin{array}{l}\text { Method } 5 \text { (One } \\
\text { measurement) }\end{array}$ & Lower part of the auricle lobe-Pogonion (soft tissue) \\
\hline $\begin{array}{l}\text { Method } 6 \text { (Three } \\
\text { measurements) }\end{array}$ & $\begin{array}{l}\text { Mandibular angle-Lateral corner of eye, Lower part of the auricle lobe-Pogonion } \\
\text { (soft tissue), and Upper part of the auricle lobe-Pogonion (soft tissue) }\end{array}$ \\
\hline $\begin{array}{l}\text { Method } 7 \text { (Three } \\
\text { measurements) }\end{array}$ & $\begin{array}{l}\text { Lower part of the auricle lobe-Labial comissura, Lower part of the auricle lobe- } \\
\text { Pogonion (soft tissue), and Upper part of the auricle lobe-Pogonion (soft tissue) }\end{array}$ \\
\hline $\begin{array}{l}\text { Method } 8 \text { (Three } \\
\text { measurements) }\end{array}$ & $\begin{array}{l}\text { Mandibular angle-Lateral corner of eye, Mandibular angle-Labial comissura, and } \\
\text { Upper part of the auricle lobe-Pogonion (soft tissue) }\end{array}$ \\
\hline $\begin{array}{l}\text { Method } 9 \text { (Three } \\
\text { measurements) }\end{array}$ & $\begin{array}{l}\text { Mandibular angle-Lateral corner of eye, Lower part of the auricle lobe-Labial } \\
\text { comissura, and Lower part of the auricle lobe-Pogonion (soft tissue) }\end{array}$ \\
\hline $\begin{array}{l}\text { Method } 10 \text { (Three } \\
\text { measurements) }\end{array}$ & $\begin{array}{c}\text { Mandibular angle-Ala nasi, Lower part of the auricle lobe- Pogonion (soft tissue), } \\
\text { and Upper part of the auricle lobe-Pogonion (soft tissue) }\end{array}$ \\
\hline $\begin{array}{l}\text { Method } 11 \text { (Three } \\
\text { measurements) }\end{array}$ & $\begin{array}{c}\text { Mandibular angle-Ala nasi, Lower part of the auricle lobe-Lateral corner of eye, and } \\
\text { Upper part of the auricle lobe-Pogonion (soft tissue) }\end{array}$ \\
\hline $\begin{array}{l}\text { Method } 12 \text { (Four } \\
\text { measurements) }\end{array}$ & $\begin{array}{l}\text { Mandibular angle-Lateral corner of eye, Mandibular angle-Ala nasi, Mandibular } \\
\text { angle-Labial comissura, and Mandibular angle-Pogonion (soft tissue) }\end{array}$ \\
\hline
\end{tabular}

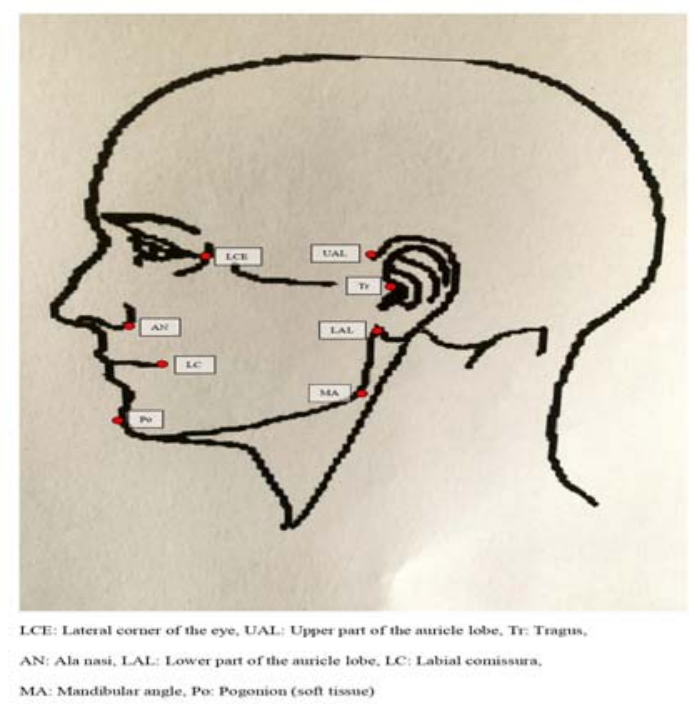

Figure 1. Points used in measurements 
Kaplan ve ark. / Comparison of swelling evaluation methods

Table 2: Comparison of swelling between genders independent of methods

\begin{tabular}{lcccccc}
\hline & $\mathrm{N}$ & Mean & $\mathrm{SD}$ & Minimum & Maximum & $\mathrm{p}$ \\
\hline Measurements in Male & 180 & 7.105337 & 3.6689659 & .0000 & 16.8831 & ${ }^{\mathrm{a}} 0.033^{*}$ \\
Measurements in Female & 132 & 6.256979 & 3.1298748 & .0000 & 20.8333 & \\
Total & 312 & 6,746416 & 3.4713687 & .0000 & 20.8333 & \\
\hline
\end{tabular}

${ }^{a}$ Oneway Anova Test; SD: Standard deviation; ${ }^{*} \mathrm{p}<0.05$

Table 3: Swelling change rates according to methods

\begin{tabular}{lllllllll}
\hline & \multicolumn{1}{l}{$2^{\text {nd }}$ day } & \multicolumn{7}{l}{$7_{\text {th day }}$} \\
\hline Group & EMM $(\%)$ & SD & Min & Max & EMM $(\%)$ & SD & Min & Max \\
Method 1 & 5.815 & 3.818 & 0 & 13.044 & 1.851 & 2.702 & 0 & 8.7 \\
Method 2 & 6.057 & 2.986 & 0 & 12.727 & 1.736 & 1.932 & 0 & 7.22 \\
Method 3 & 6.496 & 2.46 & 1.98 & 11.392 & 1.713 & 1.591 & 0 & 6.45 \\
Method 4 & 6.743 & 2.561 & 1.639 & 11.539 & 1.648 & 2.196 & 0 & 8.67 \\
Method 5 & 8.704 & 4.853 & 0 & 20.833 & 2.326 & 2.673 & 0 & 8.33 \\
Method 6 & 6.645 & 3.07 & 2.247 & 14.286 & 1.861 & 1.596 & 0 & 4.94 \\
Method 7 & 7.208 & 3.693 & 1.191 & 16.883 & 1.85 & 1.858 & 0 & 5.19 \\
Method 8 & 5.968 & 3.203 & 1.266 & 13.889 & 1.658 & 1.645 & 0 & 5.48 \\
Method 9 & 8.177 & 3.352 & 2.941 & 14.516 & 1.793 & 1.594 & 0 & 6.45 \\
Method 10 & 6.651 & 3.55 & 1.099 & 16.456 & 1.915 & 1.82 & 0 & 5.06 \\
Method 11 & 5.849 & 4.054 & 0 & 16.177 & 1.815 & 1.831 & 0 & 5.88 \\
Method 12 & 6.645 & 2.712 & 2.299 & 12.5 & 1.636 & 1.634 & 0 & 6.25 \\
F $_{\text {Day }}=118.426 ; \mathrm{p}=0.001:$ & $\mathrm{F}_{\text {Method }}=0.079 ; \mathrm{p}=0.780: \mathrm{F}_{\text {Day x Method }}=0.174 ; \mathrm{p}=0.679$ & & \\
\hline
\end{tabular}

EMM: Estimated marjinal mean; SD: Standard deviation

with a type I error of 0.05 and about $80 \%$ power. The calculations for sample size yielded a size of $24\left(\mathrm{n}=\mathrm{Z}^{2} \sigma^{2} / \mathrm{d}^{2}\right)$. Data are presented as descriptive statistics (median, mean, standard deviation, minimum, and maximum). The normality of the data was assessed using the Shapiro-Wilks test. The data were analyzed by using Repeated Measures ANOVA and multiple-comparison tests with Bonferroni corrections $(\alpha=.05)$. Pearson correlation analyses were calculated to determine the relationship between methods. The statistical analysis was conducted by using software (IBM SPSS Statistics for Windows, Version 20.0; Armonk, NY: IBM Corp) and the significance level was set to .05 in calculations.

\section{Results}

Of the 30 operated patients, 4 were excluded due to not attending their follow-up appointments regularly (3 patients) or due to inconsistency in their data (1 patient). Of the 26 remaining patients, $57.7 \%(n=15)$ were male and $42.3 \%$ $(\mathrm{n}=11)$ were female. These patients had a mean age of $23.85 \pm 6.06$ years, ranging from 18 to 40.According to swelling measurements, males (7.105 \pm 3.669$)$ had more swelling than females

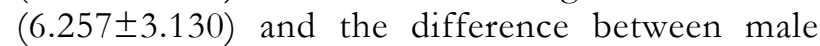
and female was statistically significant $(\mathrm{p}<0.05)$ (Table 2). Table 3 gives the results of swelling change rates using different metric methods.Examining the day 2 correlations of the methods, at least twice measurements were performed with different distances, there were significant correlations between methods 1 and 4 $(\mathrm{r}=0.63, \mathrm{p}<0.01)$, methods 6 and $11(\mathrm{r}=0.66$, $\mathrm{p}<0.01)$, methods 7 and $8 \quad(\mathrm{r}=0.63, \mathrm{p}<0.01)$, methods 7 and $11(\mathrm{r}=0.62, \mathrm{p}<0.01)$, and methods 9 and $10(\mathrm{r}=0.48, \mathrm{p}<0.05)$ (Table 4).Examining the day 7 correlations of the methods, at least twice measurements were performed with different distances, there were significant correlations between methods 1 and $4(\mathrm{r}=0.68$, $\mathrm{p}<0.01)$, methods 3 and $6(\mathrm{r}=0.48, \mathrm{p}<0.05)$, methods 3 and $9(\mathrm{r}=0.48, \mathrm{p}<0.05)$, methods 3 and $10(\mathrm{r}=0.40, \mathrm{p}<0.05)$, methods 3 and $11(\mathrm{r}=0.46$, $\mathrm{p}<0.05)$, methods 6 and $11 \quad(\mathrm{r}=0.62, \mathrm{p}<0.01)$, methods 6 and $12(\mathrm{r}=0.43, \mathrm{p}<0.05)$, methods 7 
Table 4: Correlation analysis of swelling measurement methods on $2^{\text {nd }}$ day

\begin{tabular}{|c|c|c|c|c|c|c|c|c|c|c|c|c|}
\hline & $\begin{array}{l}\text { Method } \\
1\end{array}$ & $\begin{array}{l}\text { Method } \\
2\end{array}$ & $\begin{array}{l}\text { Method } \\
3\end{array}$ & $\begin{array}{l}\text { Method } \\
4\end{array}$ & $\begin{array}{l}\text { Method } \\
5\end{array}$ & $\begin{array}{l}\text { Method } \\
6\end{array}$ & $\begin{array}{l}\text { Method } \\
7\end{array}$ & $\begin{array}{l}\text { Method } \\
8\end{array}$ & $\begin{array}{l}\text { Method } \\
9\end{array}$ & $\begin{array}{l}\text { Method } \\
10\end{array}$ & $\begin{array}{l}\text { Method } \\
11\end{array}$ & $\begin{array}{l}\text { Method } \\
12\end{array}$ \\
\hline $\begin{array}{l}\text { Method } \\
1\end{array}$ & 1 & & & & & & & & & & & \\
\hline $\begin{array}{l}\text { Method } \\
2\end{array}$ & $0.92^{* * *}$ & 1 & & & & & & & & & & \\
\hline $\begin{array}{l}\text { Method } \\
3\end{array}$ & 0.25 & 0.32 & 1 & & & & & & & & & \\
\hline $\begin{array}{l}\text { Method } \\
4\end{array}$ & $0.63^{* *}$ & $0.72^{* * *}$ & $0.46^{*}$ & 1 & & & & & & & & \\
\hline $\begin{array}{l}\text { Method } \\
5\end{array}$ & -0.26 & -0.25 & -0.03 & -0.19 & 1 & & & & & & & \\
\hline $\begin{array}{l}\text { Method } \\
6\end{array}$ & -0.05 & 0.08 & 0.11 & -0.03 & $0.58^{* *}$ & 1 & & & & & & \\
\hline $\begin{array}{l}\text { Method } \\
7\end{array}$ & -0.06 & -0.11 & 0.02 & -0.18 & $0.73^{* * *}$ & $0.84^{* * *}$ & 1 & & & & & \\
\hline $\begin{array}{l}\text { Method } \\
8\end{array}$ & 0.19 & 0.28 & 0.39 & 0.23 & 0.17 & $0.81^{* * *}$ & $0.63^{* *}$ & 1 & & & & \\
\hline $\begin{array}{l}\text { Method } \\
9\end{array}$ & -0.16 & -0.05 & 0.05 & -0.04 & $0.88^{* * *}$ & $0.57^{* *}$ & $0.72^{* * *}$ & 0.21 & 1 & & & \\
\hline $\begin{array}{l}\text { Method } \\
10\end{array}$ & 0.05 & 0.03 & 0.26 & 0.01 & $0.59^{* *}$ & $0.84^{* * *}$ & $0.88^{* * *}$ & $0.84^{* * *}$ & $0.48^{*}$ & 1 & & \\
\hline $\begin{array}{l}\text { Method } \\
11\end{array}$ & 0.23 & 0.15 & 0.27 & 0.06 & 0.09 & $0.66^{* *}$ & $0.62^{* *}$ & $0.88^{* * *}$ & 0.03 & $0.82^{* * *}$ & 1 & \\
\hline $\begin{array}{l}\text { Method } \\
12\end{array}$ & 0.16 & 0.24 & $0.93^{* * *}$ & $0.48^{*}$ & -0.08 & 0.09 & -0.05 & 0.39 & -0.05 & 0.23 & 0.27 & 1 \\
\hline
\end{tabular}

${ }^{* * *} \mathrm{p}<0.001 ;{ }^{* *} \mathrm{p}<0.01 ;{ }^{*} \mathrm{p}<0.05$ 
Kaplan ve ark. / Comparison of swelling evaluation methods

Table 5: Correlation analysis of swelling measurement methods on $7^{\text {th }}$ day

\begin{tabular}{|c|c|c|c|c|c|c|c|c|c|c|c|c|}
\hline & $\begin{array}{l}\text { Method } \\
1\end{array}$ & $\begin{array}{l}\text { Method } \\
2\end{array}$ & $\begin{array}{l}\text { Method } \\
3\end{array}$ & $\begin{array}{l}\text { Method } \\
4\end{array}$ & $\begin{array}{l}\text { Method } \\
5\end{array}$ & $\begin{array}{l}\text { Method } \\
6\end{array}$ & $\begin{array}{l}\text { Method } \\
7\end{array}$ & $\begin{array}{l}\text { Method } \\
8\end{array}$ & $\begin{array}{l}\text { Method } \\
9\end{array}$ & $\begin{array}{l}\text { Method } \\
10\end{array}$ & $\begin{array}{l}\text { Method } \\
11\end{array}$ & $\begin{array}{l}\text { Method } \\
12\end{array}$ \\
\hline $\begin{array}{l}\text { Method } \\
1\end{array}$ & 1 & & & & & & & & & & & \\
\hline $\begin{array}{l}\text { Method } \\
2\end{array}$ & $0.93^{* * *}$ & 1 & & & & & & & & & & \\
\hline $\begin{array}{l}\text { Method } \\
3\end{array}$ & -0.16 & 0.15 & 1 & & & & & & & & & \\
\hline $\begin{array}{l}\text { Method } \\
4\end{array}$ & $0.68^{* *}$ & $0.86^{* * *}$ & 0.37 & 1 & & & & & & & & \\
\hline $\begin{array}{l}\text { Method } \\
5\end{array}$ & -0.33 & -0.36 & 0.12 & -0.31 & 1 & & & & & & & \\
\hline $\begin{array}{l}\text { Method } \\
6\end{array}$ & -0.32 & -0.24 & $0.48^{*}$ & -0.18 & $0.76^{* * *}$ & 1 & & & & & & \\
\hline $\begin{array}{l}\text { Method } \\
7\end{array}$ & -0.11 & -0.18 & 0.12 & -0.28 & $0.76^{* * *}$ & $0.88^{* * *}$ & 1 & & & & & \\
\hline $\begin{array}{l}\text { Method } \\
8\end{array}$ & -0.17 & 0.04 & $0.76^{* * *}$ & 0.12 & 0.30 & $0.79^{* * *}$ & $0.55^{*}$ & 1 & & & & \\
\hline $\begin{array}{l}\text { Method } \\
9\end{array}$ & -0.16 & 0.01 & $0.48^{*}$ & 0.10 & $0.75^{* * *}$ & $0.75^{* * *}$ & $0.68^{* *}$ & $0.54^{* *}$ & 1 & & & \\
\hline $\begin{array}{l}\text { Method } \\
10\end{array}$ & -0.23 & -0.21 & $0.40^{*}$ & -0.22 & $0.74^{* * *}$ & $0.94^{* * *}$ & $0.89^{* * *}$ & $0.79^{* * *}$ & $0.64^{* *}$ & 1 & & \\
\hline $\begin{array}{l}\text { Method } \\
11\end{array}$ & 0.04 & 0.09 & $0.46^{*}$ & 0.02 & 0.19 & $0.62^{* *}$ & $0.55^{* *}$ & $0.84^{* * *}$ & 0.29 & $0.75^{* * *}$ & 1 & \\
\hline $\begin{array}{l}\text { Method } \\
12\end{array}$ & -0.07 & 0.23 & $0.94^{* * *}$ & $0.48^{*}$ & 0.12 & $0.43^{*}$ & 0.08 & $0.74^{* * *}$ & $0.43^{*}$ & 0.39 & $0.46^{*}$ & 1 \\
\hline
\end{tabular}

${ }^{* * *} \mathrm{p}<0.001 ;{ }^{* *} \mathrm{p}<0.01 ;{ }^{*} \mathrm{p}<0.05$ 
and $8(\mathrm{r}=0.55, \mathrm{p}<0.05)$, methods 7 and $11(\mathrm{r}=0.55$, $\mathrm{p}<0.01)$, methods 8 and $9(\mathrm{r}=0.54, \mathrm{p}<0.01)$, methods 9 and $10(\mathrm{r}=0.64, \mathrm{p}<0.01)$, methods 9 and $12(\mathrm{r}=0.43, \mathrm{p}<0.05)$, methods 10 and 11 $(\mathrm{r}=0.75, \mathrm{p}<0.001)$, methods 10 and $12(\mathrm{r}=0.43$, $\mathrm{p}<0.05)$, and methods 11 and $12(\mathrm{r}=0.46, \mathrm{p}<0.05)$ (Table 5).

\section{Discussion}

Edema occurs due to tissue trauma as a result of an inflammatory reaction to surgical intervention, reducing the comfort of life $(26,27)$.

Previous studies have found that gender has significant effect on the amount of swelling in patients undergoing impacted third molar tooth surgery, while others found no difference between genders $(28,29)$. In this study, more swelling was observed in males compared to females $(\mathrm{p}<0.05)$.

Despite the many methods to measure the amount of swelling on the face after surgery, accurate measurement is difficult to achieve due to the topographic characteristics of the area. Measuring an irregular convex surface requires measurements in three dimensions to reflect the swelling in the inner and outer sections (30). However, due to the many disadvantages of using 3D measurement methods, researchers often prefer the metric measurement method, which has been accepted in the literature (20,31-34). While facial swelling can be evaluated via lateral/anteroposterior graphs and photographs, these methods have disadvantages such as not allowing 3D examination, exposure to radiation, and requiring excessive work (35). Although allowing precise 3D measurement, computed tomography has been abandoned in recent years due to its disadvantages such as high costs and unnecessary radiation exposure (36,37). Another useful method after impacted third molar tooth surgery, ultrasonography has the major disadvantage of potentially causing mechanical irritation in the tissue $(31,38)$. While yielding reliable swelling evaluation on-demand, 3D scanners are complex, costly, and time-consuming to use and interpret $(21,39)$. VAS swelling scales where patients carry out evaluations themselves have also been used often in previous studies (40-42). Nonetheless, some researchers find their reliability controversial for including subjective evaluations by patients $(22,43)$. Research comparing the metric method and different methods are scarce. Ulu and Akçay compared metric measurement and 3DMD face scanning system, reporting that either could be used as an alternative to each other (21). Afat et al. examined the correlation between metric measurement and VAS swelling scale and reported that both could be used in evaluating swelling (22). To the best of our knowledge, there is no study comparing the effectiveness of different metric methods in swelling evaluation. In this study, 12 different metric measurement methods were compared in 26 patients, and postoperative day 2 and day 7 results were found to have similar effects. At least 3 lines of different anatomical points were found to be effective and sufficient in evaluating facial edema, provided they include the angulus and the masseter muscle region. In conclusion, as a result of the present study; twelve swelling evaluation methods showed significantly similar results and the authors recommended using Method 1 and 5 for convenient clinical evaluation which could be performed with a smaller number of anatomical points.

Conflict of Interests: The authors have no conflict of interest.

Acknowledgments: The authors thank Duygu Korkmaz for her assistance in the statistical evaluation of the data and review of methodology.

\section{References}

1. Micó-Llorens JM, Satorres-Nieto M, Gargallo-Albiol J, Arnabat-Domínguez J, Berini-Aytés L, Gay-Escoda C. Efficacy of methylprednisolone in controlling complications after impacted lower third molar surgical extraction. Eur J Clin Pharmacol 2006;62(9):693-698.

2. Markovic A, Todorovic L. Effectiveness of dexamethasone and low-power laser inminimizing oedema after third molar surgery: a clinical trial. Int J Oral Maxillofac Surg 2007;36(3):226-229.

3. Kissane JM. Anderson"s Pathology. 9th ed. Volume 1, Mosby Company St. Louis, 1990. p 67-90.

4. Brochner AC, Toft P. Pathophysiology of the systemic inflammatory response after major accidental trauma. Scan J Trauma Resusc Emerg Med 2009;17(1):43.

5. Bui CH, Seldin EB, Dodson TB. Types, frequencies, and risk factors for complications after third molar extraction. J Oral Maxillofac Surg 2003;61(12):13791389.

6. Uçok C. Stereophotogrammetric assessment of the effect of tenoxicam on facial swelling subsequent to third molar 
surgery. Int J Oral Maxillofac Surg 1997;26(5):380-382.

7. Llewelyn J, Ryan M, Santosh C. The use of magnetic resonance imaging to assess swelling after the removal of third molar teeth. Br J Oral Maxillofac Surg 1996;34(5):419-423.

8. Cigerim L, Kaplan V. Evaluation of the analgesic efficacies of Dexketoprofen Trometamol and Dexketoprofen Trometamol Thiocolchicoside combinationsin the impacted third molar surgery: Randomised clinical trial. Med Oral Patol Oral Cir Bucal 2019;24(1):e114e122.

9. Ulu M, Akçay H. Ödemin Değerlendirilmesinde Yüz Tarama Sistemi ile Pletismografik Ölçüm Yöntemin Karşılaştırılması. SDÜ Sağlık Bilimleri Dergisi 2019;10(1):48-52.

10. Afat İM, Akdoğan ET, Gönül O, Göker M. Evaluation of correlation between patients subjective VAS edema scores and surgeons measurement scores on face after surgical removal of impacted mandibular third molars. Yeditepe J Dent 2018;14(1):25-30.

11. Carrillo SJ, Calatayud J, Manso JF, Barberia E, Martinez MJ, Donado M. A randomized double-blind clinical trial on effectiveness of helium-neon laser in the prevention of pain, swelling and trismus after removal of impacted third molars. Int Dent J 1990;40(1):31-36.

12. Koyuncu BÖ, Zeytinoğlu M, Tetik A, Gomel MM. Effect of tube drainage compared with conventional suturing on postoperative discomfort after extraction of impacted mandibular third molars. Br J Oral Maxillofac Surg 2015;53(1):63-67.

13. Koçer G, Yuce E, Tuzuner Oncul A, Dereci O, Koskan O. Effect of the route of administration of methylprednisolone on oedema and trismus in impacted lower third molar surgery. Int J Oral Maxillofac Surg 2014;43(5):639-643.

14. Peterson LJ, Ellis E, Hupp JR, Tucker MR. Contemporary oral and maxillofacial surgery. 4th ed. St. Louis, Mosby; 2003.

15. Fragiskos FD. Oral Surgery. 1st ed. Springer, Berlin, Heidelberg; 2007. p 181203.
16. De Santana-Santos T, De Souza-Santos JAS, Martins-Filho PRS, da Silva LCF, De Oliveira e Silva ED, Gomes ACA. Prediction of postoperative facial swelling, pain and trismus following third molar surgery based on preoperative variables. Med Oral Patol Oral Cir Bucal 2013;18(1):e65-e70.

17. Silva LD, Reis EN, Faverani LP, Bassi AP. The efficacy of etodolac and ibuprofen, regarding gender, on pain, edema and trismus after impacted lower third molar surgery: A randomized prospective clinical split-mouth study. Med Oral Patol Oral Cir Bucal 2020;26(2):e136-e140.

18. Bamgbose BO, Akinwande JA, Adeyemo WL, Ladeinde AL, Arotiba GT, Ogunlewe MO. Effects of co-administered dexamethasone and diclofenac potassium on pain, swelling andtrismus following third molar surgery. Head Face Med 2005;1:11.

19. Pallagatti S, Sheikh S, Puri N, Mittal A, Singh B. To evaluatethe efficacy of ultrasonography compared to clinicaldiagnosis, radiography and histopathological findingsin the diagnosis of maxillofacial swellings. Eur J Radiol 2012;81(8):1821-1827.

20. Maal TJ, van Loon B, Plooij JM, Rangel F, Ettema AM, Borstlap WA, et al. Registration of 3-dimensional facial photographs for clinical use. J Oral Maxillofac Surg 2010;68(10):2391-2401.

21. Van Gool AV, Ten Bosch JJ, Boering G. A photographic method of assessing swelling following third molar removal. Int J Oral Surg 1975;4(3):121-129.

22. Cathcart RA. Inflammatory swellings of the head and neck. Surgery (Oxford) 2015;33(12):600-606.

23. Yamamoto S, Miyachi H, Fujii H, Ochiai $\mathrm{S}$, Watanabe $\mathrm{S}$, Shimozato $\mathrm{K}$. Intuitive facial imaging method for evaluation of postoperative swelling: a combination of 3-dimensional computed tomography and laser surface scanning in orthognathic surgery. J Oral Maxillofac Surg 2016;74(12):2506.e1-2506.e10.

24. Siegert R. Ultrasonography of Inflammatory Soft Tissue Swellings of the Head and Neck. J Oral Maxillofac Surg 1987;45(10):842-846. 
25. Harrison JA, Nixon MA, Fright WR, Snape L. Use of hand-held laser scanning in the assessment of facial swelling: a preliminary study. Br J Oral Maxillofac Surg. 2004;42(1):8-17.

26. Chaudhary M, Singh M, Singh S, Singh SP, Kaur G. Primary and secondary closure techniquefollowing removal of impacted mandibular third molars: A comparative study. Natl J Maxillofac Surg. 2012;3(1):10-14.

27. Absi EG, Shepherd JP. A comparison of morbidity following the removal of lower third molars by the lingual split and surgical bur methods. J Oral Maxillofac Surg. 1993;22(3):149-153.

28. Mantovani E, Arduino PG, Schierano G, Ferrero L, Gallesio G, Mozzati M, et al. A split-mouth randomized clinical trial to evaluate the performance of piezosurgery compared with traditional technique in lower impacted third molar tooth removal. J Oral Maxillofac Surg. 2014;72(10):18901897. 